\title{
Students' Perceptions of Their Teachers' Performance in Teaching Engineering Drawing in Nigerian Tertiary Institutions
}

\author{
Hassan Bashir ${ }^{1,2}$, Maizam Alias ${ }^{1}$, Kahirol Moh'd Saleh ${ }^{1}$, Awang Halizah ${ }^{1}$ \\ ${ }^{1}$ Universiti Tun Hussein Onn Malaysia \\ 101 Beg Berkunci, Parit Raja, Batu Pahat, Johor, 86400, Malaysia \\ ${ }^{2}$ Federal College of Education (Technical) \\ P. M. B. 1088, Gusau, Zamfara State, Nigeria
}

DOI: $10.22178 /$ pos. $27-4$

LCC Subject Category:

LB5-3640

Received 26.09.2017

Accepted 18.10.2017

Published online 28.10.2017

Corresponding Author:

Hassan Bashir

19bashzali66@gmail.com

(C) 2017 The Authors. This

article is licensed under a

Creative Commons

Attribution 4.0 License

(c) (1)

\begin{abstract}
There have been concerns about the performance of Nigerian school teachers' in delivering occupational related courses. However, there are currently limited empirical data on this phenomenon - in particular with respect to the teaching of engineering drawing - to justify further actions from educational managers and policy makers. The aim of this study was to assess teachers' performance in teaching engineering drawing using students' perception as indicator of teachers' performance. The study utilized a cross-sectional research design method with the target population of technical education students drawn from four (4) Federal Colleges of education (Technical) in Northern Nigeria. Stratified proportionate sampling technique was used to arrive at the study sample of 253 technical education students. A specifically designed instrument, the Students' Perceptions of Teachers' Performance Scales (SPTPS) was used to gather data on the three performance dimensions namely contextual, task and adaptability performance. The exploratory factor analysis and confirmatory factor analysis methods were conducted to validate the performance constructs. The instrument has a high reliability of 0.90 based on the Cronbach Alpha method. The result of the analysis using estimation method indicates that students perceive their teachers' performance to be at a slightly above average level $(M=3.51 \pm$ 0.05 at the $95 \%$ confidence level). The teachers' task performance in particular, is found to be the least developed among the three dimension of performance while their adaptability performance is the highest while still being less than excellent. The data support the conclusion that there are aspects of teachers' performance in teaching engineering drawing that is less than excellent and in need of further enhancements.
\end{abstract}

Keywords: students' perception; teachers' performance; teaching; engineering drawing.

\section{INTRODUCTION}

Basically, education at all levels dwells on effective teaching and learning. Effective teaching and learning are indicators of quality teachers and quality teaching performance which are all determining factors of a well-designed educational system [41, 29]. Globally, teachers are noted as the most important resources in any school system and interactions between them and their students has been perceived to be a vital component in teaching and learning process. Interactions and classroom observations play a dominant role in teaching and learning processes in schools. The primary purpose of which is not only to assist teachers in improving their teaching skills, but also to evaluate how well their teaching performance is. As teachers are one of the most important mainstays of school system, the quality of their performance must continuously and systematically be evaluated.

This evaluation can be carried out in various ways as enumerated by [30], they are; Valueadded models, Classroom observation, Analysis of classroom artefacts, Teacher portfolio, Selfreport of practice and Student evaluation of teachers. The value-added models provide summary score of the contribution of various factors toward assessing gains in student achievement. There are several advantages of this evaluation model, it directly examines how a teacher contributes to student learning, it is cost-efficient and nonintrusive; it requires no classroom visits, and it reveals variations among teachers in their contributions to student learning. Teachers that 
are identified to be less effective could be provided with help and support. In contrast, the method focuses only on data from standardized tests and assumes student test scores are valid and reliable indicators of student learning. It takes the averages test scores of all students in a class and ignores their differences in learning.

Classroom observations are the most common form of teacher evaluation and vary widely in how they are conducted and what they evaluate. It is done by peers, school administrators or external evaluators, they can measure general teaching practices or subject-specific techniques and can be formally or informal. The main strength of this mode of evaluation protocols is that they are often seen as credible by multiple stakeholders. It is carried out directly to measure teaching practice as the assessor can see the full dynamics of the classroom. It is linked to student achievement, and can be used for both formative and summative evaluation. On the contrary, this form of evaluation lacks accuracy as teachers' effectiveness fluctuates as different evaluators give different scores.

Analysis of classroom artefacts, this method considers lesson plans, teacher assignments, assessments, scoring rubrics, student work, and other artefacts to determine the quality of instruction in a classroom i.e. how evaluator gathers a better understandings of how a teacher creates learning opportunities for students on a dayto-day basis to evaluate the quality of instruction. This method has the advantage of being used for both summative and formative of evaluation. It is also less labour intensive; however, it is costly, requires well trained and calibrated personal and should possess knowledge of the subject matter being evaluated.

Teacher portfolio these are a collection of materials compiled by teachers to exhibit evidence of their teaching practices, school activities, and student progress, they includes teacher lesson plans, schedules, assignments, assessments, student work samples, videos of classroom instruction and interaction, reflective writings, notes from parents, and special awards or recognitions. One of the most beneficial aspects of this evaluation its comprehensiveness as it captures effective teaching both inside and outside classroom and applicable to any grade level, subject matter, or student population. They are often seen as beneficial by teachers and administrators. On the other hand, it is time consuming on the part of the teachers, it is not validated and it is difficult to attest its accuracy, consistency in scoring, reliability and measure teaching and learning improvement.

Teachers' self-report evaluation, this is a form of evaluation that asks teachers to report on what they do in the classroom and may take the form of surveys, instructional records, or discussions. This form of evaluation focuses on specific subject matter, content areas, grade levels, or techniques that are aligned to standards. This method of evaluation has the advantages of understanding teacher's intentions, thought processes, knowledge, and beliefs which are useful for teacher self-reflection and formative purposes. This mode of evaluation is cost-efficient, capable of gathering a large variety of data. More so, consideration of teacher perception and teacher participation in their evaluations is an important factor as they are the only ones who know their abilities as it relates to their subject matter, curricular content, grade levels, or techniques that are associated to the expected yardsticks. However, the major drawback of this method of evaluation is mixed reliability and validity as selfreports responses are susceptible to biases [38, 42].

Students' evaluation of teachers Students may assess various aspects of teaching, from course content to specific teaching practices and behaviours.; although students have the most contact with their teachers and are the direct consumers of teachers' performance delivery in teaching, their ratings may be susceptible to bias because they lack adequate knowledge about the full context of teaching. However, studies validate that student rating to be considered as part of teacher performance evaluation method [52] but never as the primary evaluation benchmark [6]. There are different and sometimes conflicting views with this type of evaluation. However, despite all the difference, this process is used extensively in a growing number of tertiary institutions around the world [55]. This form of evaluation have several advantages which includes cost and time effective, requires little or no preparation, data can be gathered cautiously and most importantly monitor changes over time [57]. However, major drawback of this form of evaluation is that it collects data at one point in time rather than longi- 
tudinally and as students, they lack adequate knowledge about the background of teaching.

\section{PERFORMANCE: DEFINITION AND ASPECTS}

Employee performance is a major concern for organisations and establishments. Performance according to [49] is considered as a function of ability, opportunities and motivation. Performance is a behaviour associated with the accomplishment of expected, specified, or formal role requirements on the part of individual organizational members [8]. It means actions that add value, either directly or indirectly, to the organization's capability, achievement and accomplishment, and the fundamental elements to effective performance are a skilled and motivated workforce.

There are four facets of performance: task performance, contextual performance or organizational citizenship behaviour; adaptive performance and counterproductive performance [34, 10]. Task performance refers to employees' competency, with which he/she performs according to the main set of job tasks or the job description. It is sometimes referred to as jobspecific task proficiency, technical proficiency, or in-role performance $[14,26,12]$. It includes, for example, work quantity, work quality, and job knowledge. Teachers task performance is associated with their efforts in making thoughtful and adequate application of their cognitive ability and use of teaching aids in teaching and learning [5].

Contextual performance can be defined as individual behaviours that support the organizational, social, and psychological environment in which the technical core must function [35]. Behaviours in this category of performance include volunteering, demonstrating effort, helping and cooperating with others, following rules and procedures, and supporting organizational objectives, and they are sometimes referred to as nonjob-specific task proficiency, extra-role performance, organizational citizenship behaviour, or interpersonal relations $[33,37,13,43]$.

Adaptability performance involves acquisition of enhanced abilities and proficiency in response to changes in the work role or changing job requirements. It is an aspect of job performance that is related to organizational outcomes with regards to managing change, organizational learning and keeping up with changing customer expectations [32, 24]. Adaptability performance reflects behaviours associated with competency acquisition thus, it is referred to how well an individual performs on a changing task. Within this paradigm, the antecedents of adaptability are defined in terms of the knowledge, skill, ability, and other characteristics that relate to adaptive performance.

\section{Concept of teacher's performance}

Teachers' performance is the ability of the teacher to impart the relevant skills, knowledge using appropriate methods consistently over time to enhance students' learning and achievements. Authors [19] posited that the quality of teachers and teaching are the most dominating factors that affect learning at large scale. Additionally, teacher performance denotes teachers' ability to functions effectively in performing his teaching tasks with high skills and effort with regards to his subject matter using a sound pedagogical content that leads to student's understanding and effective learning. Thus, to achieve these in teaching performance, teachers should master their subject contents, know the characteristics of good teaching, have the knowledge of different and appropriate pedagogies, learning styles of learners and perceive their own strengths and weaknesses in teaching in order to perform their teaching responsibilities effectively. This study therefore is on the students' perception of their teachers' performance in teaching engineering drawing.

\section{Students' perception of teachers' performance in teaching}

The role of students in the instructional process is critical as their perception could influence their attitude toward engineering drawing or any other technical education subjects. Author [3] described perception as the way people judge others with who they are in contact. Generally, students usually judge their school teachers in areas such as the teachers' knowledge of the subject matter, communication ability, the choice of appropriate teaching method and the general classroom management skills. A teacher who is rated on these indices at high level is likely to enjoy the confidence, respect and admiration of his students based on their perception. The knowledge of the way the students think and perceive can aid the teacher to reflect upon and adjust his 
teaching strategies to enhance students' understanding and achievement.

Students' perceptions of teacher performance have continued to be among the most important measures for evaluating teaching effectiveness [48]. Studies examining students' perceptions are new, particularly in the field of technical education. Previous researches has investigated the relationship between students' perceptions of the learning environment and its impact on learning outcomes [56, 31, 1, 28, 15, 2, 21, 23]

For example, in a recent study by [48] three factors; teacher support, cognitive activation, and classroom management were studied and they identified these factors as the most fundamental in teaching quality. The study evaluates different latent variable modelling approaches (confirmatory factor analysis, exploratory structural equation modelling and bi-factor modelling), which are used to describe these individual perceptions with respect to their factor structure, measurement invariance and the relationships to selected educational outcomes (achievement, selfconcept, and motivation). In addition, the study found significant positive relations to educational outcomes and creates different modelling approaches of individual students' perceptions of instructional quality and provides understandings into the nature of these perceptions from an individual differences perspective.

Authors [31, 28] emphasizes on the significance of students' perceptions of their teachers' behaviour towards quality of teaching and learning and concluded that the kinds of roles the teachers assume have profound effects on the perceptions of students toward them and their self-concepts and emphasised that students' learning is more affected by the perception of teaching, than by the teaching method itself.

Author [15] stressed on students' perceptions of teaching styles and use of learning strategies from a general perspective as well. He concludes that students preferred to use learning strategies that enabled them to use time well and choose conducive learning environments. Additionally, students preferred to seek assistance from their teachers or classmates when encountering learning difficulties. Still from the general perspectives, pertaining to performances of teachers, [2] and [21] explicitly, addresses the students' perceptions of the qualities or characteristics of their teachers, results revealed that students' perception of teachers' knowledge of subject matter, attitude to work and teaching skills has a signifi- cant relationship on their students' academic performance.

The paper identifies those teacher performances deemed by students to be 'effective' or 'ineffective' and the constitution of these performances, and draws conclusions as to what educators, might learn from the students with regards to effective teaching practice. Similarly, [56] compared students' perceptions of teacher's performance in Classroom and highlighted teacher's classroom management as one of the dimensions often measured in students' perception surveys and it was found to be one of the most predictive of students' achievement gains.

On the other hand, students' perception of teachers' factors in the teaching and learning of English Language was investigated by [1]. The study found a significant relationship between teachers' attitude, method of teaching and classroom management in teaching and learning of English Language as perceived by the students. This implies that students' performance in English Language was influenced by students' perception of their teachers' attitude, method of teaching and classroom management. Additionally, [44] investigated the influence of students' perceptions on mathematics performance and the result of the study among others shows a strong positive relationship between students' performance and perception constructs such as self-confidence, interests in mathematics, teacher and learning support material as well as myths and beliefs. Furthermore, the study also found gender and age related factors to have influence in the way students perceive mathematics which significantly affect students' performance. Positive perceptions have been associated with deep learning approaches whereas negative perceptions with surface learning approach are recorded.

Researchers have generally concluded that there is a significant positive relationship between student's perception of teachers' knowledge, attitude and teaching skills as predictor of teachers' performance in teaching [25, 2, 21]. Student's perception of teachers' performance has also been regarded as an important factor in predicting teachers' performance and student learning $[22,54,21,23]$ such as teachers' knowledge, attitude and teaching skills and academic achievement. Empirically, several studies conducted in science subjects have supported the students' perception of teachers' performance and teacher performance in teaching relationship [39]. 
Therefore it can be anticipated that teachers' performance in teaching as manifested by students' perception will lead to both teacher improvement in-role and extra-role performance in teaching and students' learning and academic achievements. It is expected that similar results would be found in engineering drawing teaching in Nigerian tertiary institution, i.e., students' perception of teachers' performance would associate positively with teachers' performance in teaching engineering drawing.

Previous research on technical education in $\mathrm{Ni}$ geria focussed on Benefits and limitations of Elearning for technical drawing and graphic skills acquisition for teaching and learning [46]; Technical drawing/graphic skills acquisition for teaching and learning and challenges in technology education [16] and Students' Academic Performance in Engineering Drawing in Nigerian Polytechnics [40]. Other studies cite teacher competence or subject mastery as necessary for educational effectiveness through the lens of student ratters [4, 11]. Even though there are many studies that have been conducted and opinions made on the perception of students relating to teachers' performance in teaching, there still exist conflicting views of students' perceptions about teachers performance in teaching their courses $[53,25,13]$. It evident that limited or no attention was directed on students' perceptions in the field of technical education and engineering drawing in particular. It has therefore become imperative to investigate the students' perception of their teachers' performance in teaching engineering drawing courses.

\section{Purpose of Study and Research Question}

The purpose of this study was to investigate teachers' performance from the aspect of contextual, tasks and adaptability performance in teaching engineering drawing using students' perceptions. This study seeks to answer the question, "What are the students' perceptions of their teachers' performance from the aspect of contextual, tasks and adaptability performance in teaching engineering drawing?"

\section{METHODOLOGY}

Research design. The study adopted a quantitative descriptive cross-sectional survey research design to explore the perceptions of the students about their teachers' performance in teaching engineering drawing. The design is suitable because the because it attempts to describe, examines an event occurring at a particular place(s) and time, explain and interpret the situations as suggested by $[7,50,17]$.

Population and sample. The target population for the study were all technical education students in Federal Colleges of Education (Technical) in Northern Nigeria. Stratified proportionate sampling method was adopted for the study. Using this sampling method 253 subjects were selected based on the number of participants from each subgroup which is determined by their number about the entire population as suggested by [20, 36].

Instruments. Data were obtained using the Students' Perceptions of Teachers' Performance Scales" (SPTPS) which has been specifically developed for this study to elicit information from the students about their teachers' performance on teaching engineering drawing courses. The instrument had two sections; section ' $A$ ' which is to elicit students' demographic profile and section 'B' which examines the students' perceptions regarding their teachers' performance on three performance dimensions namely, contextual, task and adaptability. The three performance dimensions (contextual, task and adaptability performance) were identified from literature. The respondents were asked to give response to their agreements towards given statements by choosing "1" for Strongly Disagree, "2" for Disagree, " 3 " for Neutral, "4" for Agree and " 5 " for Strongly Agree". The performance structure and constructs were validated using the exploratory factor analysis (EFA) and the confirmatory factor analysis (CFA) methods to fulfil the new instrument development requirements as suggested by [9]. The validated SPTPS has a reliability of 0.90 which is categorised as of "very good" as suggested by [27].

\section{RESULTS}

Respondents Profile. There are more males than females in the sample and the distribution is typical of the general TVET sector that has a 70:30 male to female ratio. This means that the sample represents the TVET population in terms of gender distribution. Discipline wise, the largest percentage of respondents (33.6\%) were found 
to have come from the automobile department and the lowest (3.4\%) come from the engineering drawing department. Level wise, majority of students $(45.6 \%)$ are Nigeria Certificate Education (NCE III), while few $(0.4 \%)$ are at NCE I. About $(32.8 \%)$ of the technical education stu- dents had some knowledge and experience with ED from their NCE I and II classes.

Students' perceptions of their teachers' performance. Overall, teachers' performance was found to have slightly above average performance as perceived by student (Table 1 ).

Table 1 - Summary of students' mean rating scores on their perceptions of teachers' occupational task performance in teaching Engineering Drawing and Reliability

\begin{tabular}{|l|l|c|c|c|}
\hline Code & \multicolumn{1}{|c|}{ Perceived teachers' performance in teaching Engineering Drawing } & M & SD & Alpha ( $\sigma$ ) \\
\hline CNT & Teachers' contextual performance in teaching & 3.46 & 1.362 & 0.92 \\
\hline TSK & Teachers' task performance in teaching & 3.43 & 1.390 & 0.91 \\
\hline ADP & Teachers' adaptability performance in teaching) & 3.65 & 1.176 & 0.91 \\
\hline PFRM & Overall Mean (M), Standard Deviation (SD) and Reliability & 3.51 & 1.309 & 0.91 \\
\hline
\end{tabular}

Contextual performance in teaching engineering drawing. Table 2, shows that technical education students perceives their teachers contextual per- formance in teaching engineering drawing as being at the average level $(\mathrm{M}=3.46$ and $\mathrm{SD}=1.362)$.

Table 2 - Students' rating scores on their perceptions about their teachers' contextual, performance in teaching Engineering Drawing

\begin{tabular}{|l|l|c|c|}
\hline Code & \multicolumn{1}{|c|}{ Item Statements } & Mean & $\begin{array}{l}\text { Standard } \\
\text { Deviation }\end{array}$ \\
\hline CNT4 & $\begin{array}{l}\text { My teacher needs high Engineering Drawing knowledge and skills to be able to teach } \\
\text { technical education courses effectively }\end{array}$ & 3.67 & 1.441 \\
\hline CNT2 & My teacher like to learn to teach ED with computer & 3.59 & 1.489 \\
\hline CNT7 & $\begin{array}{l}\text { My teacher cooperates with his colleagues and work as a team when it comes to } \\
\text { teaching of Engineering Drawing courses }\end{array}$ & 3.53 & 1.108 \\
\hline CNT3 & $\begin{array}{l}\text { My teacher use of modern teaching techniques such as computer simulations, } \\
\text { animations, auto card, and computer aided design CAD etc to facilitate his lesson } \\
\text { delivery }\end{array}$ & 3.46 & 1.230 \\
\hline CNT6 & $\begin{array}{l}\text { My teacher cannot teach some Engineering Drawing contents because they require } \\
\text { computer and computer applications }\end{array}$ & 3.40 & 1.417 \\
\hline CNT1 & $\begin{array}{l}\text { My teacher cannot teach some Engineering Drawing contents because he is not } \\
\text { computer literate }\end{array}$ & 3.28 & 1.519 \\
\hline CNT5 & $\begin{array}{l}\text { My teacher cannot teach some Engineering Drawing contents because he doesn't how to } \\
\text { use the required computer applications }\end{array}$ & 3.25 & 1.357 \\
\hline & \multicolumn{1}{|c|}{ Total } & 3.46 & 1.362 \\
\hline
\end{tabular}

The results show that seven (7) items was used to evaluate teachers' contextual performance. This dimension of performance focuses on teachers' behaviours in teaching, which includes extrarole performance, volunteering, demonstrating effort, helping and cooperating with others, following rules and procedures, and interpersonal relations which are also referred to as non-jobspecific task proficiency. On the general note, students' perceptions of their teachers' contextual performance in teaching engineering drawing was perceives as slightly below average with mean $\mathrm{M}=3.46$ and $\mathrm{SD}=1.362$, the item CNT4 "My teacher needs high Engineering Drawing knowl- edge and skills to be able to teach technical education courses effectively" recorded the highest M score of 3.67, on the other hand, item CNT5 "My teacher cannot teach some Engineering Drawing contents because he don't how to use the required computer applications." recorded the lowest M score of 3.25 as perceived by the students.

Tasks performance in teaching engineering drawing. Students' were given eight (8) items to rate their teachers' task performance in teaching Engineering Drawing. Table 3 presents the mean and standard deviations of the 8 items in descending order. 
Table 3 - Students' rating scores on their perceptions about their teachers' task performance in teaching Engineering Drawing

\begin{tabular}{|l|l|c|c|}
\hline Code & \multicolumn{1}{|c|}{ Item Statements } & Mean & $\begin{array}{c}\text { Standard } \\
\text { Deviation }\end{array}$ \\
\hline TSK4 & My teacher teaches engineering drawing with high job skills, knowledge and accuracy & 3.61 & 1.208 \\
\hline TSK9 & $\begin{array}{l}\text { Engineering drawing course is an important course to all technical education and } \\
\text { engineering students }\end{array}$ & 3.56 & 1.366 \\
\hline TSK2 & My teacher need more time to be able to cover the course contents & 3.52 & 1.166 \\
\hline TSK3 & $\begin{array}{l}\text { My teacher completes all job tasks required of him in teaching Engineering Drawing } \\
\text { courses }\end{array}$ & 3.49 & 1.520 \\
\hline TSK6 & My teacher like the level of performance of his students in Engineering Drawing & 3.48 & 1.447 \\
\hline TSK8 & $\begin{array}{l}\text { My teacher has vast knowledgeable and competent in teaching engineering drawing } \\
\text { courses }\end{array}$ & 3.45 & 1.456 \\
\hline TSK1 & $\begin{array}{l}\text { My teacher gives us advance notice when will not be able to come for his Engineering } \\
\text { Drawing lesson }\end{array}$ & 3.44 & 1.233 \\
\hline TSK5 & $\begin{array}{l}\text { My teacher helps his students to understand engineering drawing courses contents very } \\
\text { well }\end{array}$ & 3.25 & 1.560 \\
\hline TSK7 & My teacher receives so many challenges from us while teaching Engineering Drawing & 3.25 & 1.402 \\
\hline & \multicolumn{1}{|c|}{ Total } & 3.43 & 1.390 \\
\hline
\end{tabular}

The findings shows that students perceive that their engineering drawing teachers have a moderate level of task performances in teaching engineering drawing courses $(\mathrm{M}=3.43$ and $\mathrm{SD}=1.390$ ). Furthermore, among the eight items surveyed under teachers' task performance, the students perceived their teachers to have possessed high job skills, knowledge and quality teaching in engineering drawing courses with the M score of 3.61. Conversely, item TSK7, "My teacher receives so many challenges from us while teaching Engineering Drawing" was perceived by student as average with the lowest $M$ score of 3.25. Students perceived the engineering drawing as an important course that helps them, not only to acquire the necessary knowledge and skills pertaining to the course, but to understand their area of specialization (technical and vocational education courses) as well.

Adaptability performance in teaching engineering drawing. Teachers' adaptability performance in teaching engineering drawing refers to the specific duties inherent in the job of teaching performance. The perception of students on teachers' adaptability performance in teaching engineering drawing is presented in Table 4.

Table 4 - Students' rating scores on their perceptions about their teachers' adaptability performance in teaching Engineering Drawing

\begin{tabular}{|c|c|c|c|}
\hline Code & Item Statements & Mean & $\begin{array}{l}\text { Standard } \\
\text { Deviation }\end{array}$ \\
\hline ADP4 & $\begin{array}{l}\text { My teacher efficacy in teaching Engineering Drawing is always retarded by } \\
\text { overpopulation in the class. }\end{array}$ & 3.74 & 1.078 \\
\hline ADP2 & My teacher is effective in adjusting to changes in engineering drawing class & 3.70 & 1.215 \\
\hline ADP6 & My teacher answer students' questions while teaching Engineering Drawing. & 3.67 & 1.373 \\
\hline ADP5 & $\begin{array}{l}\text { My teacher work cooperatively and helps other teachers to find a solution to any } \\
\text { difficult topics. }\end{array}$ & 3.66 & 1.223 \\
\hline ADP1 & My teacher is always ready for new challenges within the engineering drawing class. & 3.56 & 1.321 \\
\hline ADP3 & My teacher allows students to ask questions while teaching Engineering Drawing. & 3.56 & 0.846 \\
\hline & Total & 3.65 & 1.176 \\
\hline
\end{tabular}

The students' perceptions on the dimension of teachers' adaptability performance in teaching engineering drawing was evaluated by six (6) items. The construct focused on teachers' flexibil- ity in teaching efficacy, with respect to over population, changes in curriculum, sudden circumstances, teachers' specialization and competency as shown in Table 4. On the general note, students' perceptions of their teachers' adapta- 
bility performance in teaching engineering drawing was perceives as very high with mean $\mathrm{M}=3.54$ and $\mathrm{SD}=1.318$, the item ADP4 "My teacher efficacy in teaching Engineering Drawing is always retarded by overpopulation in the class" recorded the highest M score of 3.74 while item ADP3 "My college has enough specialist teachers of Engineering Drawing" recorded the lowest M score of 3.56 as perceived by the students.

\section{DISCUSSIONS}

The aim of this study is to investigate the students' perceptions of their teachers' performance in teaching engineering drawing. This study was guided by two research questions and one hypothesis. The findings of the study were based on the results of the univariate and multivariate analyses as presented in the previous sections. The study found that technical education students from six tertiary institutions in Nigeria perceived their teachers' performance in teaching engineering drawing as very high. This clearly indicates that technical education students from these institutions recognizes and acknowledges the value of their teachers' effective teaching in their engineering drawing lessons.

The overall student perceptions of teachers' performance in teaching engineering drawing yielded a very high mean scores $\mathrm{M}=3.51$. Although, the general finding of the students' perception of their teachers' performance in teaching engineering drawing was rated very high, analysis based on each component of performance shows that teachers' contextual performance generated a total mean score of $\mathrm{M}=3.46$ and $\mathrm{SD}=1.362$ which is moderately perceived by the technical education students. It is noteworthy that teacher's contextual performance is average because it consists of activities that are not formally part of one's job obligations, but supports the organizational, social and psychological environment [51]. It indirectly facilitates organization's performance by accelerating task performance of employees (teachers).

Teachers' task performance on the other hand produced a total mean score of $\mathrm{M}=3.43$ and $\mathrm{SD}=1.390$ also moderately perceived by the technical education students. While adaptability performance was perceived by the technical education students as very high with a total mean score of $\mathrm{M}=3.65$ and SD of 1.176.
Thus, it would be inferred from the mean scores that technical education teachers' best performance skills in teaching engineering drawing is adaptability performance. Adaptability according to [18] refers the ability to respond to and manage new changes, innovations, uncertain situations or events that may arise while teaching. The result of the study is in line with [47] who found that adaptive performance is multi-dimensional, encompassing a wide range of different behavioural, cognitive and emotional adjustments. In addition, [18] suggest that adaptability is an essential ability for teachers given the frequently changing nature of teachers' profession. Teachers' adaptability performance in the classroom is the capacity to positively change and respond to new circumstances; it is an essential ability a teacher needs to possess for him to effectively manage his classroom.

Teachers' task performance in teaching engineering drawing was perceived by the technical education students as moderate. The relationship between students' perception of teachers and teachers' performance in teaching engineering drawing is moderate with mean score of 3.43 . The result showed that technical education teachers accorded the desired attention to engineering drawing teaching delivery. This result of the study is in line with $[5,25]$ who found a significant relationship between teachers' instructional tasks performance and students' academic performance.

Teachers' adaptability performance was investigated and perceived by the technical education students as very high with a total mean score $M=3.65$. The result of this study is in line with [21] who studied perception of students on the qualities or characteristics of their teachers, and found those teacher performances deemed by students to be "effective" and "ineffective" and the composition of these performances and draws conclusions as to what teachers, might learn from the students with regards to effective teaching practice. Similarly, [45] noted that, adaptability is seen as an essential skills in modern education as teachers are required to make use of new teaching methods, environments, and tools in teaching and learning processes. Accordingly, working in schools requires that teachers are able to successfully respond to and deal with any changing demands that transpire across the school more broadly (e.g., changes in staffing, new curriculum, new procedures or policies). As such, adaptability performance is a capacity of 
fundamental relevance to teachers' healthy and effective functioning at work. Moreover, it is also relevant to students' academic outcomes.

One characteristic of adaptable teacher is willingness to act in new and strange situation in the process of teaching. This can be a new learning topic, a new learning environment, or a new problem to solve. Being part of teachers' performance, adaptability allows a teacher to respond to these unfamiliar situations in an efficient way to enhance understanding in his class. Adapt to varied roles, jobs responsibilities, schedules and contexts and work effectively in a climate of ambiguity and changing priorities. Effective teachers are adaptable and flexible in providing variety in their teaching activities, aiming to match their manipulation of the teaching and learning environment to the needs of the learner, but teachers should also know what type of activities they are most effective at delivering.

\section{CONCLUSION}

The result of this study indicates that students' perception of their teachers' performance is slightly above average. This is an important finding as it provides empirical data that are reflected in the current state of arts in teachers' teaching performances. Teachers, educational managers and policy makers should take note as when students' perception of their teachers' performance is low, this could result in their negative attitude towards the engineering drawing courses and vice versa. Engineering drawing teachers should therefore make every effort to demonstrate sound and effective teaching qualities to arouse their students' high perception. Managers and policy makers should provide teaching and learning environments that are adequate, suitable and conducive to both teacher and students. This will then create students' positive attitude towards engineering drawing courses. As students' attitude improves, so will their commitment and interest towards the engineering drawing courses which would lead to improvements in achievement.

\section{REFERENCES}

1. Abiola, O.-O. F. (2013). Students' Perception of Teachers' Factors in the Teaching and Learning of English Language in Nigerian Secondary Schools. Journal of Educational and Social Research, 3(3), 173-179. doi: 10.5901/jesr.2013.v3n3p173

2. Adediwura, A. A., \& Tayo, B. (2007). Perception of teacher's knowledge, attitude and teaching skills as predictor of academic performance in Nigerian secondary schools. Educational Research and Reviews, 2(7), 165-171.

3. Allport, G. W. (1935). Attitudes. In C. Murchiso (Ed.), A Handbook Social Psychology (pp. 798-844). Worchester: Clark University Press.

4. Arnon, S., \& Reichel, N. (2007). Who is the ideal teacher? Am I? Similarity and difference in perception of students of education regarding the qualities of a good teacher and of their own qualities as teachers. Teachers and Teaching, 13(5), 441-464. doi: $10.1080 / 13540600701561653$

5. Ayeni, A. J., \& Afolabi, E. R. I. (2012). Teachers' instructional task performance and quality assurance of students' learning outcomes in Nigerian secondary schools. International Journal of Research Studies in Educational Technology, 1(1), 33-42. doi: 10.5861/ijrset.2012.v1i1.47

6. Baker, E., Barton, P., Darling-Hammond, L., Haertel, E., Ladd, H., Linn, R., Ravitch, D., Rothstein, R., Shavelson, R., \& Shepard, L. (2010, August). Problems with the Use of Student Test Scores to Evaluate Teachers. Retrieved from http://www.epi.org/files/page/-/pdf/bp278.pdf

7. Bhat, D. A. (2013). Quantitative Techniques - an Applied Perspective. Journal of Research in Management \& Technology, 2(1), 35-44.

8. Bos-Nehles, A., Van Riemsdijk, M., \& Looise, J. (2013). Employee Perceptions of Line Management Performance: Applying the AMO Theory to Explain the Effectiveness of Line Managers' HRM Implementation. Human Resource Management, 52(6), 861-877. doi: 10.1002/hrm.21578 
9. Brown, T. (2015). Confirmatory Factor Analysis for Applied Research. New York: The Guilford Press.

10. Cabrera, A. F., Colbeck, C. L., \& Terenzini, P. T. (2001). Developing Performance Indicators for Assessing Classroom Teaching Practices and Student Learning. Research in Higher Education, 42(3), 327-352. doi: 10.1023/a:1018874023323

11. Çakmak, M., Akkutay, U. (2016). Effective Teaching in the Eye of Teacher Educators: A Case Study in a Higher Education. The Quality Report, 21(12), 2349-2364.

12. Campbell, C. H., Ford, P., Rumsey, M. G., Pulakos, E. D., Borman, W. C., Felker, D. B., ...

Riegelhaupt, B. J. (1990). Development of multiple job performance measures in a representative sample of jobs. Personnel Psychology, 43(2), 277-300. doi: 10.1111/j.1744-6570.1990.tb01559.x

13. Campbell, J. P. (2005). Evaluating teacher performance in higher education: the value of student ratings (Doctoral dissertation). Orlando: College of Education at the University of Central Florida.

14. Campbell, J. P., \& Wiernik, B. M. (2015). The Modeling and Assessment of Work Performance. Annual Review of Organizational Psychology and Organizational Behavior, 2(1), 47-74. doi: 10.1146/annurev-orgpsych-032414-111427

15. Chang, Y. (2010). Students' Perceptions of Teaching Styles and Use of Learning Strategies (Master's thesis). Retrieved from

http://trace.tennessee.edu/cgi/viewcontent.cgi?article=1835\&context=utk_gradthes

16. Chedi, J. M. (2015). Technical drawing/graphic skills acquisition for teaching and learning and challenges in technology education. Journal of Science, Technology, \& Education, 3(3), 128-133.

17. Cohen, L., Manion, L., Morrison, K. (2013). Research Methods in Education (7th ed.). Hoboken: Taylor and Francis.

18. Collie, R. J., \& Martin, A. J. (2016). Adaptability: An Important Capacity for Effective Teachers. Educational Practice and Theory, 38(1), 27-39. doi: 10.7459/ept/38.1.03

19. Corcoran, S. P., Evans, W. N., \& Schwab, R. M. (2014). Changing Labor-Market Opportunities for Women and the Quality of Teachers 1957-1992. Retrieved from http://www.nber.org/papers/w9180.pdf

20. Cresswell, J. W. (2002). Educational research: Planning, conducting and evaluating quantitative and qualitative research (4th ed.). Boston: Pearson.

21. Dalley-Trim, L. (2007). Students' Observations and Perceptions of Teacher "Performances" in the Classroom. Australian Journal of Teacher Education, 32(1), 17-35.

22. Dauda, B., Jambo, H. E., \& Umar, M. A. (2016). Students' Perception of Factors Influencing Teaching and Learning of Mathematics in Senior Secondary Schools in Maiduguri Metropolis, Borno State, Nigeria. Journal of Education and Practice, 7(20), 114-122.

23. Donahue, J. M. (1994). Student perceptions of their teachers, their school, and themselves as learners (Doctoral dissertation). Retrieved from http://lib.dr.iastate.edu/cgi/viewcontent.cgi?article=11693\&context=rtd

24. Dorsey, D. W., Cortina, J. M., \& Luchman, J. (2010). Adaptive and citizenship-related behaviors at work. In J. L. Farr \& N. T. Tippins (Eds.), Handbook of employee selection (pp. 463-487). New York: Routledge/Taylor \& Francis Group.

25. Duyar, I., Ras, N., \& Pearson, C. L. (2015). Analysis of teachers' task and extra-role performance under different autonomy regimes. International Journal of Productivity and Performance Management, 64(4), 499-522. doi: 10.1108/ijppm-06-2013-0103

26. Griffin, M. A., Neal, A., \& Parker, S. K. (2007). A new model of work role performance: positive behavior in uncertain and interdependent contexts. Academy of Management Journal, 50(2), 327-347. doi: 10.5465/amj.2007.24634438

27. Hair, Jr., Black, W., Babin, B., \& Anderson, R. (2014). Multivariate Data Analysis: A Global Perspective (7th ed.). Upper Saddle River: Prentice Hall. 
28. Hanover Research. (2013, February). Student Perception Surveys and Teacher Assessments. Retrieved from https://ru.scribd.com/document/205141580/Student-Perception-Surveys-andTeacher-Assessments-Membership-2

29. Hanushek, E. A., \& Rivkin, S. G. (2006). Chapter 18 Teacher Quality. Handbook of the Economics of Education, 1051-1078. doi: 10.1016/s1574-0692(06)02018-6

30. Hanushek, E., \& Wößmann, L. (2007). The Role of School Improvement in Economic Development. Retrieved from https://sites.hks.harvard.edu/pepg/PDF/Papers/PEPG07-

01_Hanushek_Woessmann.pdf

31. Ibrahim, A. (2014). The Students' Perception of Teachers ' Classroom Effectiveness on Their SelfConcepts in Lagos Metropolis. Journal of Teaching and Teacher Education, 2(2), 133-141.

32. Jundt, D. K., Shoss, M. K., \& Huang, J. L. (2014). Individual adaptive performance in organizations: A review. Journal of Organizational Behavior, 36(1), S53-S71. doi: 10.1002/job.1955

33. Koopmans, L., Bernaards, C. M., Hildebrandt, V. H., Schaufeli, W. B., de Vet Henrica, C. W., \& van der Beek, A. J. (2011). Conceptual Frameworks of Individual Work Performance. Journal of Occupational and Environmental Medicine, 53(8), 856-866. doi:

10.1097/jom.0b013e318226a763

34. Koopmans, L., Bernaards, C., Hildebrandt, V., de Vet, H., \& van der Beek, A. (2014). Measuring individual work performance: Identifying and selecting indicators. Journal of Prevention, Assessment \& Rehabilitation, 45(3), 62-81.

35. Koopmans, L., Bernaards, C., Hildebrandt, V., van Buuren, S., van der Beek, A. J., \& de Vet, H. C. W. (2012). Development of an individual work performance questionnaire. International Journal of Productivity and Performance Management, 62(1), 6-28. doi: 10.1108/17410401311285273

36. Leech, N. L., Barrett, K. C. \& Morgan, G. A. (2015). IBM SPSS for Intermediate Statistics: Use and Interpretation (5th ed.). New York: Routledge.

37. Lievens, F., Conway, J. M., \& Corte, W. (2008). The relative importance of task, citizenship and counterproductive performance to job performance ratings: Do rater source and team-based culture matter? Journal of Occupational and Organizational Psychology, 81(1), 11-27. doi: 10.1348/096317907x182971

38. Little, O., Goe, L., \& Bell, C. (2009, April). A Practical Guide to Evaluating Teacher Effectiveness. Retrieved from http://files.eric.ed.gov/fulltext/ED543776.pdf

39. Madike, V. N. (2015). Student Perceptions of Biology Teachers' Interpersonal Teaching Behaviors and Student Achievement (Doctoral dissertation). Retrieved from http://scholarworks.waldenu.edu/cgi/viewcontent.cgi?article=1519\&context=dissertations

40. Medupin, R. O., Abubakre, O. K., Adebayo, S. A., Enock, O. I., \& Sulayman, F. A. (2015). Students' Academic Performance in Engineering Drawing in Nigerian Polytechnics: A Case Study of the Federal Polytechnic Bida, Nigeria. Journal of Multidisciplinary Engineering Science and Technology, 2(2), 99-106.

41. Modebelu, M. N., \& Nwakpadolu, G. M. (2013). Effective Teaching and Learning of Agricultural Science for Food Security and National Sustainability. Journal of Educational and Social Research, 3(4), 161-170. doi: 10.5901/jesr.2013.v3n4p161

42. Moorman, R. H., \& Podsakoff, P. M. (1992). A meta-analytic review and empirical test of the potential confounding effects of social desirability response sets in organizational behaviour research. Journal of Occupational and Organizational Psychology, 65(2), 131-149. doi: 10.1111/j.2044-8325.1992.tb00490.x

43. Murphy, K. R. (1989). Dimensions of job performance. In R. F. Dillon, J. W. Pellegrino (Eds.), Testing: Theoretical and Applied Perspectives (pp. 218-247). New York: Praeger. 
44. Mutodi, P., \& Ngirande, H. (2014). The Influence of Students` Perceptions on Mathematics Performance. A Case of a Selected High School in South Africa. Mediterranean Journal of Social Sciences, 5(3), 431-445. doi: 10.5901/mjss.2014.v5n3p431

45. OECD. (2016). Education at a Glance 2016. OECD Indicators. Paris: OECD Publishing.

46. Oviawe, J. I. (2016). Benefits and Limitations of E-learning for Technical Drawing in Edo State Model Secondary Schools, Nigeria. International Journal of Academic Research in Progressive Education and Development, 5(3), 52-64. doi: 10.6007/ijarped/v5-i3/2213

47. Pulakos, E. D., Arad, S., Donovan, M. A., \& Plamondon, K. E. (2000). Adaptability in the workplace: Development of a taxonomy of adaptive performance. Journal of Applied Psychology, 85(4), 612624. doi: $10.1037 / 0021-9010.85 .4 .612$

48. Scherer, R., Nilsen, T., \& Jansen, M. (2016). Evaluating Individual Students' Perceptions of Instructional Quality: An Investigation of their Factor Structure, Measurement Invariance, and Relations to Educational Outcomes. Frontiers in Psychology, 7, 1-16. doi: 10.3389/fpsyg.2016.00110

49. Shah, S., Jaffari, A., Aziz, J., Ejaz, W., Ul-Haq, I., \& Raza, S. (2011). Workload and Performance of Employees. Interdisciplinary Journal of Contemporary Research in Business, 3(5), 256-267.

50. Shuttleworth, M. (2008). How to choose the most Appropriate design? Retrieved from http://www.experiment-resources.com/different-research-methods.html

51. Sonnentag, A., Volmer, J., \& Spychala, A. (2010). Job Performance. In J. Barling (Ed.), Micro approaches (pp. 427-447). Los Angeles: SAGE.

52. Spooren, P., Brockx, B., \& Mortelmans, D. (2013). On the Validity of Student Evaluation of Teaching: The State of the Art. Review of Educational Research, 83(4), 598-642. doi: 10.3102/0034654313496870

53. Steinberg, M. P., \& Garrett, R. (2016). Classroom Composition and Measured Teacher Performance: What Do Teacher Observation Scores Really Measure? Educational Evaluation and Policy Analysis, 38(2), 293-317. doi: 10.3102/0162373715616249

54. Sutcliff, C. (2011). Secondary Students' Perceptions of Teacher Quality (Doctoral dissertation). Retrieved from http://digitalcommons.georgiasouthern.edu/cgi/viewcontent.cgi?article=1391\&context=etd

55. Taheri, M., Ryasi, H., Afshar, M., \& Mofatteh, M. (2014). Comparison between student rating, faculty self-rating and evaluation of faculty members by heads of respective academic departments in the school of medicine in Birjand University of Medical Sciences in Iran. Journal of Education and Health Promotion, 3(4), 34-41.

56. Vonkova, H., Zamarro, G., DeBerg, V., \& Hitt, C. (2015). Comparisons of Student Perceptions of Teacher's Performance in the Classroom: Using Parametric Anchoring Vignette Methods for Improving Comparability. Retrieved from

http://www.uaedreform.org/downloads/2015/05/comparisons-of-student-perceptions-ofteachers-performance-in-the-classroom-using-parametric-anchoring-vignette-methods-forimproving-comparability.pdf

57. Worrell, F. C., \& Kuterbach, L. D. (2001). The Use of Student Ratings of Teacher Behaviors With Academically Talented High School Students. Journal of Secondary Gifted Education, 12(4), 236247. doi: $10.4219 /$ jsge-2001-670 